\title{
LOW DISPERSION OF ANOPHELINE MALARIA VECTORS in the African equatorial forest
}

\author{
LE GOFF G., CARNEVALE P. \& ROBERT V**
}

\section{Summary :}

Previous studies showed that the anophelines, vectors of human malaria, had densities especially high on the banks of the large rivers flowing through the rain forest in the South of Cameroon. In order to establish if these mosquitoes enter or not into the forest, samplings were performed with CDC light traps placed in houses distant of less than $200 \mathrm{~m}$ from the banks of the Sanaga river and in houses at $1.5 \mathrm{~km}$ from this river. In houses at less than $200 \mathrm{~m}$ from the bank, the mean densities of Anopheles nili and An. gambiae were respectively 40 and 5 times higher than at $1.5 \mathrm{~km}$. Thus the rain forest constitute a significant obstacle for the dispersion of anophelines. Therefore confining of anophelines at the immediate surroundings of the river permits to explain why anopheline densities are such important at low distances of the river and not in the rest of the forest.

KEY WORDS : Anopheles nili, An. gambiae, bioecology, malaria, river, equatorial forest, South Cameroon.

MOTS-CLÉS : Anopheles nili, An. gambiae, bioécologie, paludisme, fleuve, forêt équatoriale, Sud Cameroun.

\section{INTRODUCTION}

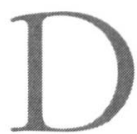

ensities of human malaria transmitting anophelines, are usually low in tropical rain forest zones and moderate seasonal variations are observed (Mouchet et al., 1993). A documented exception concerns villages situated near a permanent river where the river bed provides appropriate larval breeding sites for anophelines like Anopheles nili, An. gambiae and An. moucheti (Mouchet et al., 1962). River side villages can show high anopheline density reaching a mean of 29 bites/man/night along the Sanaga river (Carnevale et al., 1992) when this mean density is usually inferior to three bites/man/night in forest villages far from any river (Le Goff et al., 1993). The aim of this study was to observe if these high densities stretched out further than the immediate proxi-

\footnotetext{
* Institut français de recherche pour le développement en coopération (ORSTOM), Organisation de Coordination pour la lutte contre les Endémies en Afrique Centrale (OCEAC), BP 288, Yaoundé, Cameroun.

Correspondence: Vincent Robert, Laboratoire de Paludologie, BP 1386, Dakar, Sénégal, E-mail: Vincent.Robert@orstom.sn.
}

Résumé : FAIBLE DISPERSION DES ANOPHÈlES VeCTEURS DE PALUdISME DANS LA FORÊT ÉQUATORIALE AFRICAINE

Des études précédentes ont montré que les anophèles vecteurs de paludisme humain, présentaient des densités particulièrement élevées sur les berges des grands fleuves qui s'écoulent dans la forêt équatoriale du Sud Cameroun. Pour savoir si ces moustiques pénètrent ou non dans la forêt, leur échantillonnage a été effectué à l'aide de pièges lumineux du type CDC placés dans des maisons distantes de moins de 200 mètres des berges du fleuve Sanaga et dans des maisons à $1,5 \mathrm{~km}$ du fleuve. Dans les maisons situées à moins de $200 \mathrm{~m}$ du fleuve, les densités moyennes d'Anopheles nili et d'An. gambiae étaient respectivement 40 fois et 5 fois plus élevées qu'à $1,5 \mathrm{~km}$ du fleuve. La forêt équatoriale constitue donc un réel obstacle à la dispersion des anophèles. Leur confinement dans les abords immédiats du fleuve permet d'expliquer pourquoi les densités anophélienne sont si élevées près du fleuve et si faibles dans le reste de la forêt. mity of the river. Culicidian relative densities on the river banks and at a distance of $1.5 \mathrm{~km}$ from the river have been compared.

\section{MATERIALS AND METHODS}

1 he study was performed in four traditional hamlets in the rainy forest of Southern Cameroon (Fig. 1). Each hamlet had about 200 inhabitants. Three hamlets (Nkong-Mango, Tombi, Mbébé) were on the left banks of the Sanaga river, situated at less than $200 \mathrm{~m}$. The fourth (Somakaii) was situated at $1,5 \mathrm{~km}$ from the river.

Mosquito catches took place each month for three nights running, between $20.00 \mathrm{~h}$ and $06.00 \mathrm{~h}$ in four different houses: two houses in Somakaï and two houses in one of the hamlets on the bank of the river. A switch of the capture hamlets on the river bank allowed to obtain one capture session monthly in every hamlet on the river bank.

Sampling of culicidian populations has been performed with CDC Miniature Light Traps (Sudia \& Chamberlain, 1962) as already used in Central Africa (Carnevale 


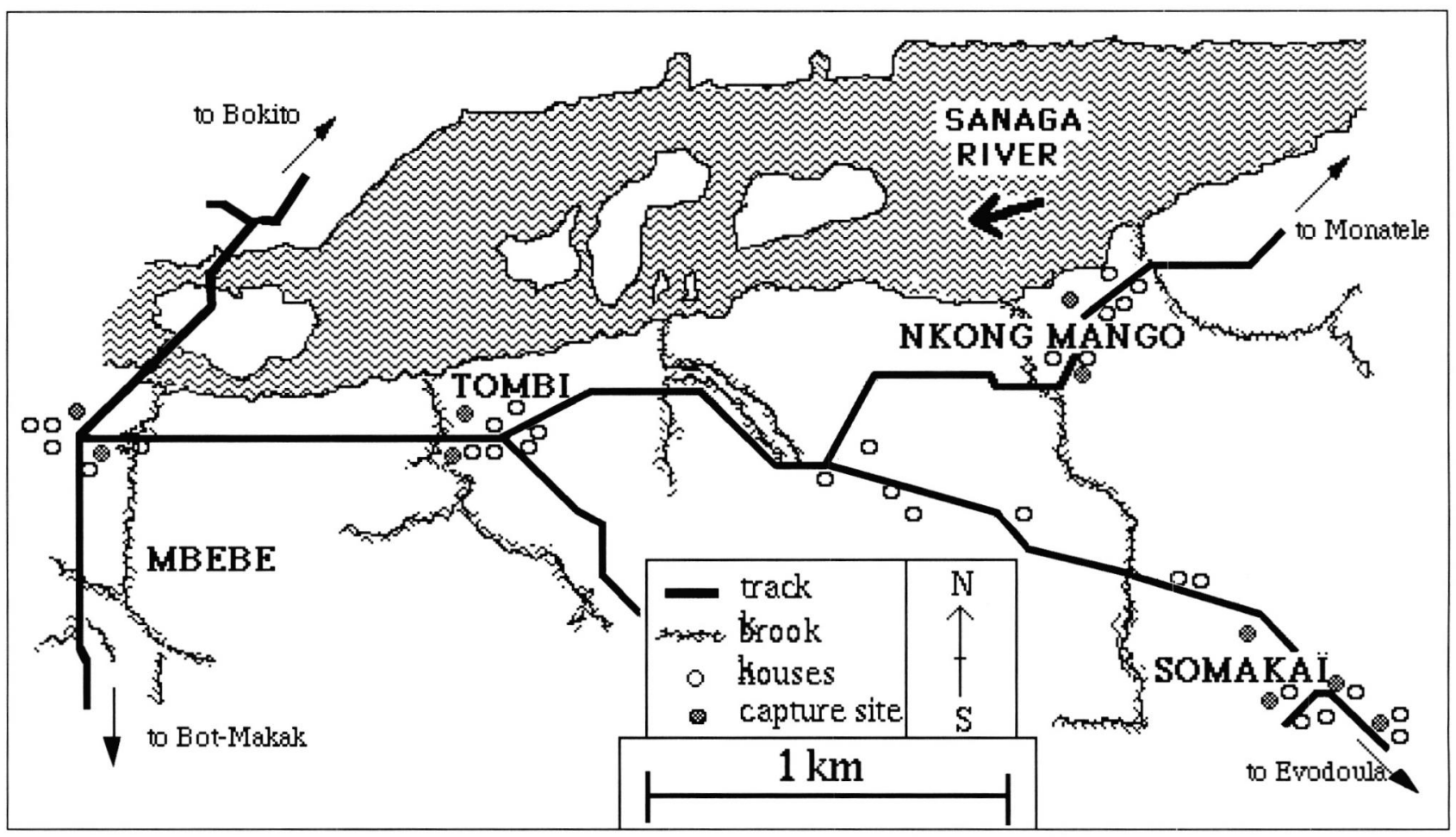

Fig. 1. - Mbebe-Kikot area and localisation of hamlets and houses included in the study. The large arrow indicate the sens of the current.

\& Le Pont, 1973). In general the trap was placed in a sleeping room where someone was actually sleeping. Exposed results concerned exclusively female mosquitoes (Diptera: Culicidae). An. gambiae design only An. gambiae s.s., sole member of the An. gambiae complex observed in this area (Robert et al., 1993).

\section{RESULTS}

$\mathrm{F}$ rom August 1989 to January 1990, 18 nightly capture sessions permitted to perform 32 trapnights at Somakai and 33 trap-nights in the villages on the river banks.

At Somakaï, 611 mosquitoes catched belonged to four culicidian genera of which $52(8.5 \%)$ of the genus Anopheles (Table I). In the other villages, 1861 mosquitoes were collected of which 1,729 (92.9\%) were of the genus Anopheles. There was a significant difference between the Anopheles distribution in the catches in Somakaï and the other villages $\left(\chi^{2}=1,626\right.$; $\left.\mathrm{p}<10^{-9}\right)$. The distribution of the genus Anopheles for the captures realised in the villages on the river bank was homogenous: $89.3 \%$ at Nkong-Mango, $96.3 \%$ at Tombi and $89.3 \%$ at Mbébé.

At Somakaï, light traps sampled 41 An. nili (78.8\%), 9 An. gambiae (17.3\%), 1 An. funestus (1.9\%) and 1 An. paludis (1.9\%), respectively. In the villages on the

\begin{tabular}{l|cc}
\hline $\begin{array}{c}\text { Name } \\
\text { of the hamlets }\end{array}$ & Somakaï & $\begin{array}{c}\text { Nkong Mango, } \\
\text { Tombi, Mbébé }\end{array}$ \\
\hline $\begin{array}{c}\text { Distance } \\
\text { from the river }\end{array}$ & $1.5 \mathrm{~km}$ & $<200 \mathrm{~m}$ \\
\hline \multicolumn{1}{c|}{$\begin{array}{c}\text { Number } \\
\text { of collections }\end{array}$} & 32 & 33 \\
\hline $\begin{array}{l}\text { Anopheles gambiae } \\
\text { Anopheles nili }\end{array}$ & $9(1.5 \%)$ & $50(2.7 \%)$ \\
$\begin{array}{c}\text { Anopheles funestus } \\
\text { Anopheles paludis } \\
\text { total Anophelinae }\end{array}$ & $1(6.7 \%)$ & $1,677(90.1 \%)$ \\
\hline $\begin{array}{c}\text { Mansonia africana } \\
\text { et M. uniformis }\end{array}$ & $1(0.2 \%)$ & $2(0.1 \%)$ \\
Culex spp & $34(8.5 \%)$ & $1,729(92.9 \%)$ \\
Aedes aegypti & $211(34.5 \%)$ & $46(2.5 \%)$ \\
total Culicinae & $1(0.2 \%)$ & $86(4.6 \%)$ \\
\hline Total & $559(91.5 \%)$ & $132(7.1 \%)$ \\
\hline
\end{tabular}

Table I. - Mosquitoes female collected with CDC light-traps from August 1989 to January 1990 in houses situated on river banks and at $1.5 \mathrm{~km}$ from the Sanaga river (Mbébé area, South Cameroun).

river bank, the light traps have permitted to collect 1,677 An. nili, 50 An. gambiae et 2 An. funestus corresponding with 97.0, 2.9 and $0.1 \%$ of the catches. There was a significant difference in the distribution for An. nili and An. gambiae between Somakaï and 
the other villages (Bilateral Fisher's Exact test, $p<10^{-6}$ for An. nili; p $<10^{-4}$ for An. gambiae).

The mean number of $A n$. nili per trap and per night was 50.82 on the river bank and 1.28 in Somakaï; the ratio was 39.7. The mean number of $A n$. gambiae per trap and per night was 1.52 on the river bank and 0.28 in Somakaï; the ratio was 5.4 .

\section{DISCUSSION}

T he densities of $A n$. nili were almost 40 times higher in the villages situated on the bank of the river than in the village of Somakai situated at $1.5 \mathrm{~km}$ from the river. Therefore, the dispersion of An. nili away from the river was very low. Their dispersion was limited by the presence of a dense forest and by the large possibility to satisfy the need for human blood meals. This observation have to be related with the ecology of $A n$. nili which depends on running streams, both for breeding and oviposition sites.

The density of An. gambiae was five times higher in the villages on the river bank in comparison with Somakaï. De Meillon (1937) and Adams (1940) described that the dispersion of An. gambiae in the open savannah in Zambia reaches 3 to $6.5 \mathrm{~km}$. In a dense forest zone, the bed of a major. river is a permissive site for the proliferation of this major vector of human malaria. The larvae of An. gambiae s.s. are heliophilic and do not develop in the undergrowth (Mouchet \& Gariou, 1961). The river opens the canopy permitting sunshine to go strait on the emerging rock poolsand creating of potential larval breeding sites favourable for the development of this anopheline species.

In conclusion, in the rain forest of South-Cameroon, the bed of important rivers allows the proliferation of anophelines, vectors of human malaria. The villages in the immediate surroundings of the river present elevated anopheline densities. These densities decrease rapidly according to the distance from the river. The low dispersion of anophelines in forest can be related to the dense vegetal cover and perhaps also to their unfavourable maintenance in the equatorial forest.

\section{ACKNOWLEDGEMENTS}

$\mathrm{T}$ he authors gratefully acknowledge JeanClaude Toto for technical assistance and Bert Mulder for reviewing the manuscript. This study was financially supported by the Institut français de recherche pour le développement en coopération (ORSTOM), by the Organisation de Coordination pour la lutte contre les Endémies en Afrique Centrale (OCEAC) and by the French Ministery of Cooperation.

\section{REFERENCES}

ADAmS P.C.G. Some observations on the flight of stained anopheles at Nkana, Northern Rhodesia. Annals of Tropical Medicine and Parasitology, 1940, 34, 35-45.

Carnevale P., Le Goff G., Toto J.-C. \& Robert V. Anopheles nili as the main vector of malaria in villages of southern Cameroon. Medical and Veterinary Entomology, 1992, 6, 135-138.

Carnevale P. \& Le Pont F. Épidémiologie du paludisme humain en République Populaire du Congo. II. Utilisation des pièges lumineux "CDC " comme moyen d'échantillonnage des populations anophèliennes. Cabiers ORSTOM, série Entomologie médicale et Parasitologie, 1973, 11, 263-273.

De Meillon B. A note on Anopheles gambiae and An. funestus in Northern Rhodesia. Publication of the South African Institute of Medical Researche, 1937, 7, 306-401.

Le Goff G., Toto J.C., Nzeyimana I., Gouagna L.C. \& ROBERT V. Les moustiques et la transmission du paludisme dans un village du bloc forestier sud-Camerounais. Bulletin de Liaison et de Documentation de l'OCEAC, 1993 , 26, 133-137.

Mouchet J., Carnevale P., Coosemans M., Fontenille D., Ravaonjanahary C., Richard A. \& Robert V. Typologie du paludisme en Afrique. Cahiers Santé, 1993, 3, 220-238.

Mouchet J. \& GARIOU J. Répartition géographique et écologique des anophèles au Cameroun. Bulletin de la Société de Pathologie exotique, 1961, 54, 102-118.

Mouchet J. Influence des fleuves sur la biologie d'Anopheles gambiae pendant la saison sèche dans le Sud-Cameroun. Bulletin de la Société de Pathologie exotique, 1962, 55 , 1163-1171.

Robert V., Petrarca V., Le Goff G. \& Manga L. Quelques données cytogénétiques sur le complexe Anopheles gambiae au Sud-Cameroun. Bulletin de Liaison et de Documentation de l'OCEAC, 1993, 26, 99-101.

Sudia W. D. \& Chamberlain R. W. Battery-operated light trap, an improved model. Mosquito News, 1962, 22, 126-129.

Reçu le 18 novembre 1996 Accepté le 6 février 1997 